\title{
Population structure of Sind sardinella Sardinella sindensis (Day, 1878) in northern Persian Gulf and Oman Sea, Iran
}

\author{
ALI SALARPOURI ${ }^{1,2}$, EHSAN KAMRANI ${ }^{2}$, FARHAD KAYMARAM ${ }^{3}$ \\ RASOOL MAHDAVI NAJAFABADI ${ }^{4}$ AND MEHRNAZ GHANBARZADEH 5 \\ ${ }^{1}$ Persian Gulf and Oman Sea Ecological Research Institute, Iranian Fisheries Science Research Institute (IFSRI) \\ Agricultural Research, Education and Extension Organization (AREEO), Bandar Abbas, Tehran, Iran \\ ${ }^{2}$ Fisheries Department, Faculty of Marine Sciences and Technologies, University of Hormozgan, P. O. Box 3995 \\ Bandar Abbas, Iran \\ ${ }^{3}$ Iranian Fisheries Science Research Institute (IFSRI), Agricultural Research, Education and Extension Organization \\ (AREEO), Bandar Abbas, Tehran, Iran \\ ${ }^{4}$ Department of Natural Resources Engineering, University of Hormozgan, P. O. Box 3995, Bandar Abbas, Iran \\ ${ }^{5}$ Department of Marine biology, Faculty of Marine Sciences and Technologies, University of Hormozgan, P. O. Box 3995 \\ Bandar Abbas, Iran \\ e-mail: salarpouri@pgoseri.ac.ir
}

\section{ABSTRACT}

\begin{abstract}
The population dynamics of Sardinella sindensis (Day, 1878) was studied from samples in the commercial fishery in the coastal waters of the Persian Gulf and Oman Sea. A total of 12,898 specimens were collected through monthly sampling of boat purse seine and beach seine catches. Total length of the sampled fishes ranged from 5.0 to $19.9 \mathrm{~cm}$. The von Bertalanffy growth parameters determined using monthly length frequency distribution were asymptotic length $\left(\mathrm{L}_{\infty}=21 \mathrm{~cm}\right)$, growth coefficient $\left(\mathrm{K}=1.2\right.$ year $\left.{ }^{-1}\right)$ and age at zero length $\left(\mathrm{t}_{0}=-0.14\right.$ year). The estimated value for longevity $\left(\mathrm{t}_{\max }\right)$ was 2.5 years. The probability of capture was calculated as $\mathrm{Lc}_{25}=10.2 \mathrm{~cm}, \mathrm{Lc}_{50}=10.9 \mathrm{~cm}$ and $\mathrm{Lc}_{75}=11.8 \mathrm{~cm}$ total length. Four cohorts with mean lengths of $7.2,11.7,15.7$ and $18.6 \mathrm{~cm}$ were discerned in a year, with two recruitment peaks. The calculated length-weight equation was $\mathrm{W}=0.0078 \mathrm{~L}^{3.02}$. The instantaneous rates of mortality $(\mathrm{Z})$ was estimated as 4.02 , with natural mortality $\mathrm{M}=2.19$ and fishing mortality $\mathrm{F}=1.83$ year $^{-1}$. The exploitation rate $(\mathrm{E})$ was 0.46 , which was found to be reasonable for current fishing effort. From the yield-per-recruit analysis, $\mathrm{E}_{\max }$ was estimated as 0.79 , confirming that the stock is under optimum exploitation.
\end{abstract}

Keywords: Growth parameters, Mortality rate, Oman Sea, Persian Gulf, Sardinella sindensis

\section{Introduction}

Small pelagic fishes (anchovies and sardines) usually found in marine areas with high primary production (Ganias, 2014) support vast fisheries systems around the world (Schwartzlose et al., 1999; Bakun, 2010; King, 2013). Management of small pelagic fisheries is very difficult because of wide variability in population size (Cushing, 1971; Blaxter and Hunter, 1982). These fishes, especially, sardines are among the world's most important marine resources (Devaraj et al., 1997; Kesteven et al., 1981; FAO, 2011), mainly because of their relative ease of capture with purse seiners (owing to the schooling behaviour) and capacity to reach enormous biomasses in some populations (Cole and McGlade, 1998). Sind sardinella, Sardinella sindensis (Day, 1878) is a pelagic clupeoid species that inhabits the coastal waters of the Persian Gulf and Oman Sea (FAO, 1981; Whitehead, 1985; Randall, 1995). Sardines are short-lived and fast growing species, characterised by considerable fluctuations in their stock size because of their high dependence on highly variable, environmentally-driven annual recruitment pulses (Barange et al., 2009). Sind sardinella is widely distributed in Indian west coast, Pakistan, the Oman Sea, the Persian Gulf and also occurs from the Arabian Sea to the Gulf of Aden (Whitehead, 1985). The potential yield of small pelagic fishes in the Persian Gulf and Oman Sea was estimated to be around 4,00,000 t, 60\% of which corresponds to sardines (FAO, 1981).

Sind sardinella is a dominant species of sardine in the coastal waters of the Persian Gulf and Oman Sea (FAO, 1981; Owfi, 1991; Van Zailinge et al., 1993). The average landing of purse seiners was estimated to be $500 \mathrm{t}$ per year in the Persian Gulf (FAO, 2011). Fishing season of small pelagic fishes in the Persian Gulf and Oman Sea starts from early autumn to late spring (Alizade and Oliaei, 2015). Over $98 \%$ of small pelagic fishes in the 
Iranian adjacent waters are distributed in the three major fishing grounds including Bandar-lengeh, Qeshm Island and Bandar-Jask (Qorbanzadeh and Nazari, 2012). Catch of 57,000 t of small pelagic fishes (35\% sardines and 65\% anchovies) was reported by Alizade and Oliaei (2015) from the study area. Sardines, which are a major food source for tuna and mackerel fishes, have an important ecological role in the Persian Gulf and Oman Sea. Sardines have been found to constitute $15-60 \%$ of long tail tuna diet (Shawghi, 1992; Darvishi et al., 2003) and 45\% of Spanish king mackerel diet (Darvishi, 2008). Information on small pelagic resources in the Persian Gulf and Oman Sea are available from the works of Lazarus (1980), FAO (1981), Sivakumaran et al. (1987), Van Zailinge et al. (1993) and Iran (1998). Much of the previous research on fishery, biology and stock assessment of sardines occurred in different locations such as: the biology of Sardinella longiceps in the Sultanate of Oman (Al-Barwani et al., 1989), stock assessment of lesser sardines in the Indian waters (Bennet et al., 1992), biology and stocks of sardines from the Persian Gulf (Owfi, 1994), reproduction of Sardinella sp. in Pakistan waters (Khatoon and Hussain, 1998) and age, growth and mortality rates of S. longiceps off Oman Sea (Al-Anbouri et al., 2012). Very little is known about the population structure and the exploitation levels of $S$. sindensis in the Persian Gulf and Oman Sea; the only studies being of Safa (2011) and Rahimi et al. (2016). The present study investigated some aspects of the population biology of $S$. sindensis in the Persian Gulf and
Oman Sea along the coast of Iran, including the population structure, size, age, growth, mortality and length-weigh relationship, in order to provide information required for the proper management of the species in this area.

\section{Materials and methods}

\section{Study area}

The study area included three major fishing areas viz., Bandar-Lengeh, Qeshm Island and Bandar-Jask of small pelagic fishes in the northern coastal waters of the Persian Gulf and Oman Sea between lat 52 30' E and $58^{\circ} 30^{\prime} \mathrm{E}$ (Fig. 1). These areas have a high level of biodiversity which support a wide variety of fish species.

\section{Data collection}

Samples of $S$. sindensis were collected monthly from October 2014 to September 2015 from purse seine and beach seine catches by simple random sampling, from the commercial fishery in the Persian Gulf and Oman Sea fishing grounds. On each sampling day, random sub-samples of fish were obtained from well-mixed catches. For each specimen, the total length and the total weight were recorded to the nearest $\mathrm{cm}$ and $\mathrm{g}$, respectively. Everymonth, at least 350 fish weremeasured from each sampling area, except where the catches were quite poor. The chosen sample size provided a reasonable database for analysis (Gulland and Rosenberg, 1992). A total of 12,898 specimens of $S$. sardinella were collected

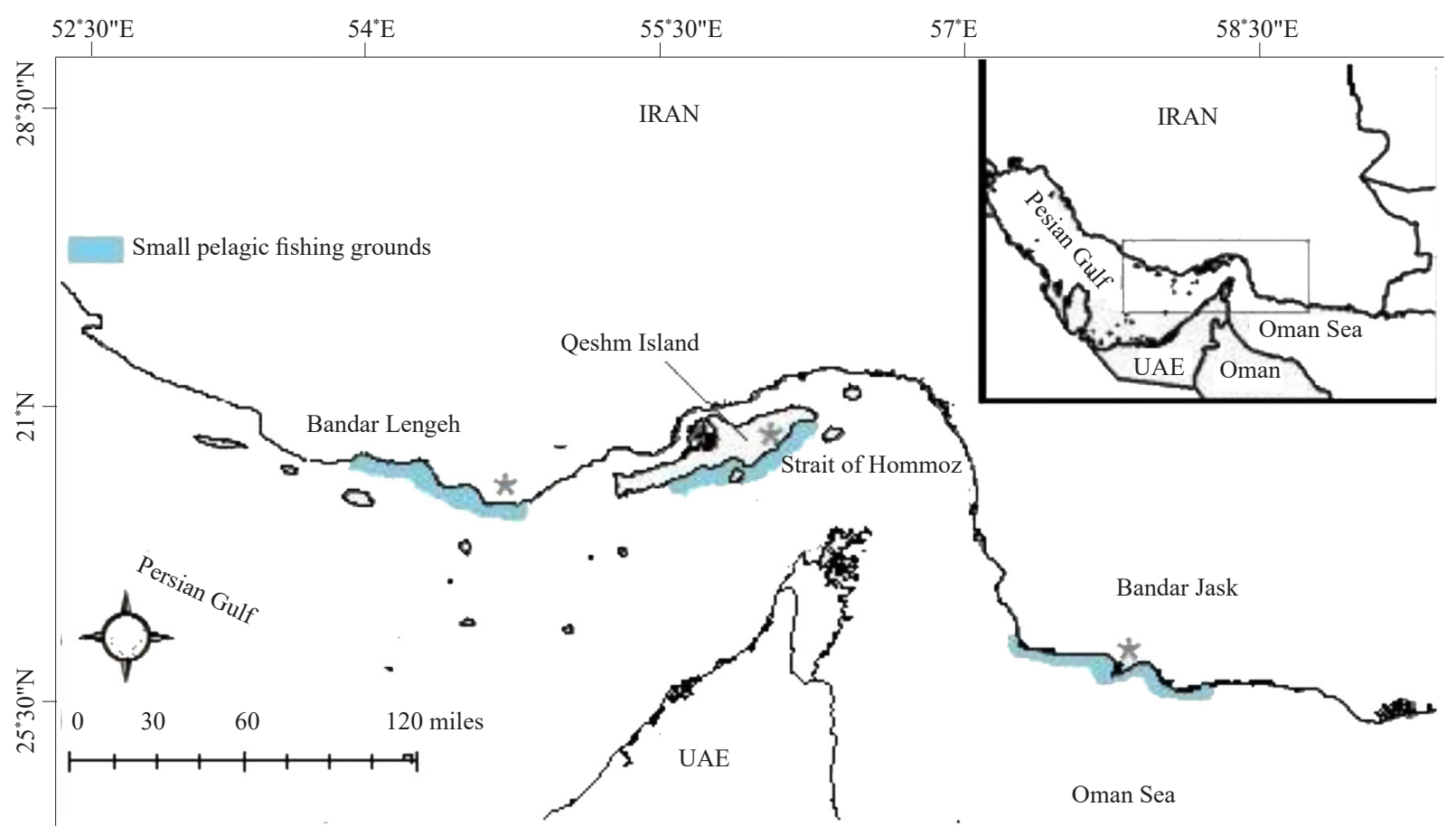

Fig. 1. Map of the study area (* indicates sampling sites) 
for length frequency. Also, length-weight details were recorded in 2,111 specimens sampled.

\section{Data analysis}

Since $S$. sindensis in the three study areas belong to a unit stock (Safa, 2011; Rahimi et al., 2016), the length frequency data were pooled and analysed following the methods given by Sparre and Venema (1998). The relationship between total length and total weight was derived by regression through linear transformation of the exponential equation:

$\mathrm{W}=\mathrm{aL}$

The length data was classified into 16 length classes of $1 \mathrm{~cm}$ interval, as suggested by Gayanilo et al. (2005). Growth parameters of the von Bertalanffy growth function (VBGF) were determined using ELEFAN I routine of the FiSAT (FAO-ICLARM Stock Assessment Tools) program (Gayanilo and Pauly, 1997). The VBG equation was used to describe growth in length (Sparre and Venema, 1998):

$\mathrm{L}_{\mathrm{t}}=\mathrm{L}_{\infty}\left[1-\exp \left(-\mathrm{k}\left(\mathrm{t}-\mathrm{t}_{0}\right)\right)\right]$

where $\mathrm{L}_{\mathrm{t}}=$ total length of the fish at time $\mathrm{t}$, $\mathrm{L}_{\infty}=$ asymptotic length, $\mathrm{K}=$ annual growth coefficient and $\mathrm{t}_{0}=$ hypothetical time when the total length of the fish is zero (Sparre and Venema, 1998) and $t_{0}$ was estimated by the empirical function given by Pauly (1983):

$\log _{10}\left(-\mathrm{t}_{0}\right)=-0.3922-0.2752 \log _{10}\left(\mathrm{~L}_{\infty}\right)-1.830 \log _{10}(\mathrm{~K})$

The seeded value of $\mathrm{L}_{\infty}\left(\mathrm{L}_{\max }=\right.$ the largest length observed in this study) was $19.9 \mathrm{~cm}$ total length. The VBG parameters of $S$. sardinella obtained in this study was compared with estimates documented for other sardines, using the formula given by Pauly and Munro (1984):

$\emptyset=\log _{10} \mathrm{~K}+2 \log _{10} \mathrm{~L}_{\infty}$

The total instantaneous mortality rate (Z) was calculated from the length-converted catch curve using the program ELEFAN I. Natural mortality (M) was estimated by Pauly's empirical formula (Pauly, 1980):

$\log _{10}(\mathrm{M})=-0.0066-0.279 \log _{10}\left(\mathrm{~L}_{\infty}\right)+0.6543 \log _{10}(\mathrm{~K})$ $+0.4634 \log _{10}(\mathrm{~T})$

in which a mean annual surface temperature (T) of $27^{\circ} \mathrm{C}$ was used (Ebrahimi et al., 2012; Ebrahimi et al., 2006; Ebrahimi et al., 2005). Fishing mortality (F) was estimated from the equation: $Z=\mathrm{M}+\mathrm{F}$. The exploitation rate $(E)$ was estimated using the formula: $E=F / Z$.

The probability of capture was estimated from the left ascending arm of the length-converted catch curve. By plotting the cumulative probability of capture against mid-length, a resultant curve was obtained, from which the length at first capture $\left(\mathrm{Lc}_{50}\right)$ was obtained, corresponding to the cumulative probability at $50 \%$. The entire length-frequency data were used to reconstruct the seasonal recruitment pattern of the fish by projecting backward along a trajectory defined by the computed VBG function; all the restructured length-frequency data were set according to a 1-year time scale (Pauly, 1987). The potential longevity (the age of the oldest fish sampled) of $S$. sardinella was calculated using the following formula (Pauly and Munro, 1984) :

$\mathrm{t}_{\max }=\mathrm{t}_{0}+3 / \mathrm{K}$

The relative yield-per-recruit model of Beverton and Holt (1957) modified by Pauly and Soriano (1986) was used to estimate the relative yield-per-recruit and relative biomass-per-recruit, according to a selection ogive. The computed exploitation rate was compared with the expected values of $E_{\text {max }}$ (the value of $E$ which gives the maximum relative yield-per-recruit), $\mathrm{E}_{0.1}$ (the value of $\mathrm{E}$ at which the marginal increases in $\mathrm{Y} / \mathrm{R}$ and is $10 \%$ of its value at $\mathrm{E}=0$ ) and $\mathrm{E}_{0.5}$ (the value of $\mathrm{E}$ at $50 \%$ of the unexploited relative biomass-per-recruit) (Gayanilo and Pauly, 1997; Sparre and Venema, 1998). The yield isopleths diagram was used to assess the impacts of the changes of the exploitation rate $(\mathrm{E})$ and the ratio of the length at first capture to the asymptotic length $\left(\mathrm{Lc}_{50} / \mathrm{L}_{\infty}\right)$ in relation to changes of mesh size, on the yield.

\section{Results}

The total length and weight of individuals ranged from 5.0 to $19.9 \mathrm{~cm}$ with a mean of $13.0 \mathrm{~cm}$ and from 3.9 to $63.3 \mathrm{~g}$ with a mean of $17.9 \mathrm{~g}$ during the study period. The length frequency distribution of the sampled fishes is shown in Fig. 2.

The calculated length-weight equation (sexes pooled) was $\mathrm{W}=0.00785 \mathrm{~L}^{3.02}$ (Fig. 3). The slope (b value) of the length-weight relationship was not significantly different $\left(\chi^{2}\right.$-test; $\left.p<0.05\right)$ from the theoretical value of 3 for all

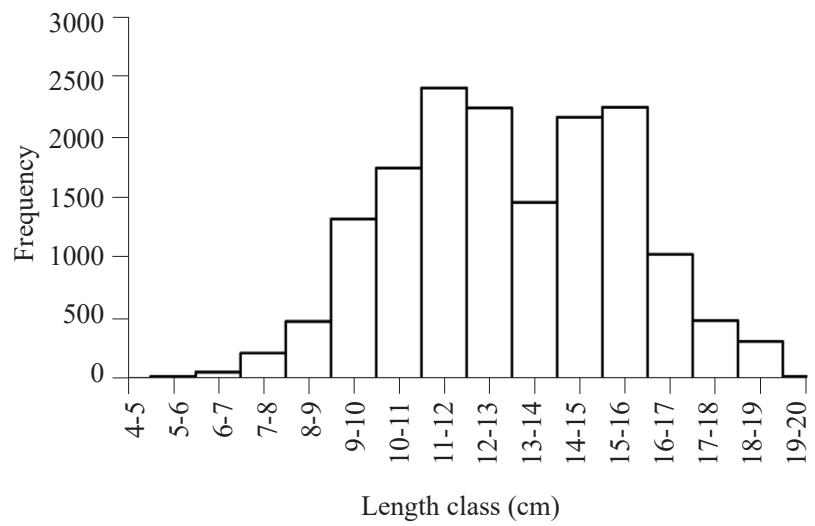

Fig. 2. Length frequency distribution of $S$. sindensis 


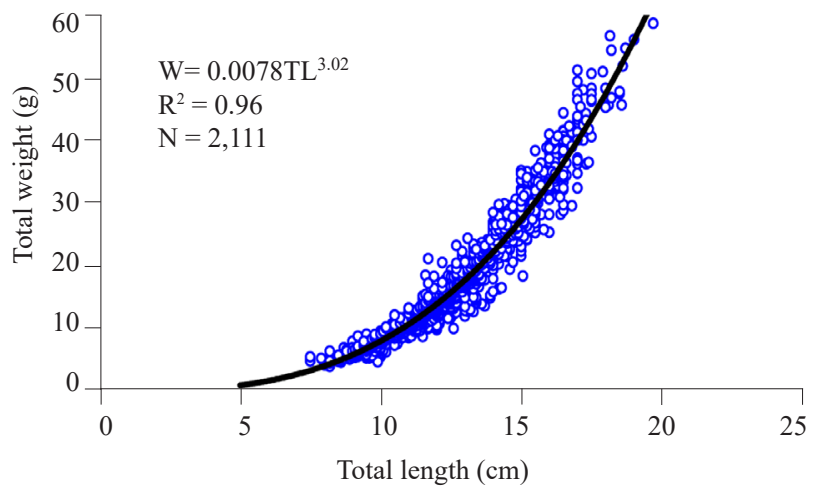

Fig. 3. Length-weight relationship curve for S. sindensis

individuals which indicates isometric pattern of growth in S. sardinella.

The best estimates of growth parameters obtained using ELEFAN I routine were $\mathrm{L}_{\infty}=21.0 \mathrm{~cm}, \mathrm{~K}=1.2$ year $^{-1}$, and $\mathrm{t}_{0}=-0.14$ year (Fig. 4 ). Growth performance index (Ø) was estimated as 2.72 . The potential longevity $\left(\mathrm{t}_{\max }\right)$ of $S$. sardinella was estimated at 2.5 years, or approximately 30 months. Four cohorts with the mean lengths of $7.24,11.69,15.65$ and $18.55 \mathrm{~cm}$ were determined annually using the Bhattacharya's method. The recruitment pattern indicated two peaks per year (Fig. 5). A major recruitment peak occurred at 22\% in April.

The length-converted catch curve is shown in Fig. 6. The instantaneous rates of mortality for all fish were estimated as $Z=4.02$ year $^{-1}, M=2.19$ year $^{-1}$ and $F=1.83$ year $^{-1}$. The exploitation rate (E) was 0.46 . The probability of capture was calculated as $\mathrm{Lc}_{25}=10.18 \mathrm{~cm}, \mathrm{Lc}_{50}=10.97 \mathrm{~cm}$ and $\mathrm{Lc}_{75}=11.77 \mathrm{~cm}$ total length (Fig. 7).

Relative yield-per-recruit and relative biomass-perrecruit were calculated using ogive selection. Yield-perrecruit isopleths diagram with $\mathrm{M} / \mathrm{K}=1.82$ for $S$. sindensis is shown in Fig. 8. The yield contours predicted the response of the relative yield-per-recruit of the fish to changes in $\mathrm{Lc}_{50}$ and $\mathrm{E} ; \mathrm{Lc}_{50} / \mathrm{L}_{\infty}=0.52 . \mathrm{Lc}_{50} / \mathrm{L}_{\infty}$ values represent different scenarios of changes in mesh size. E corresponds to the level of changes of $F / Z$. The optimum exploitation

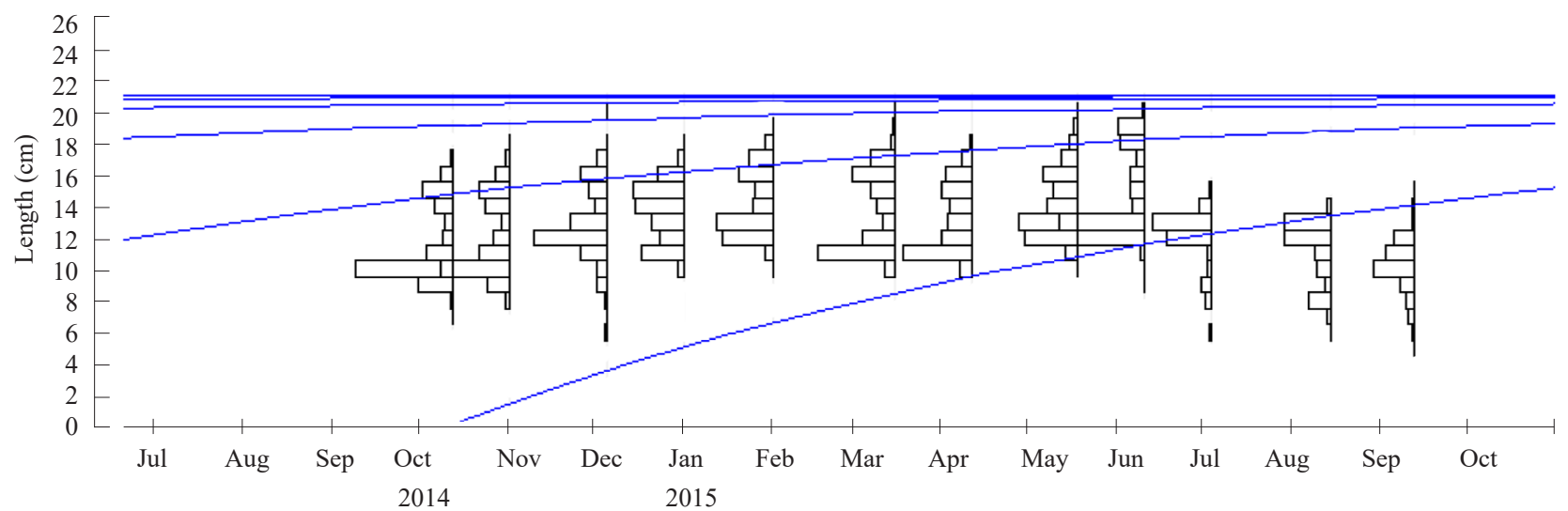

Fig. 4. Restructured length-frequency histogram for S. sindensis with superimposed growth curve.

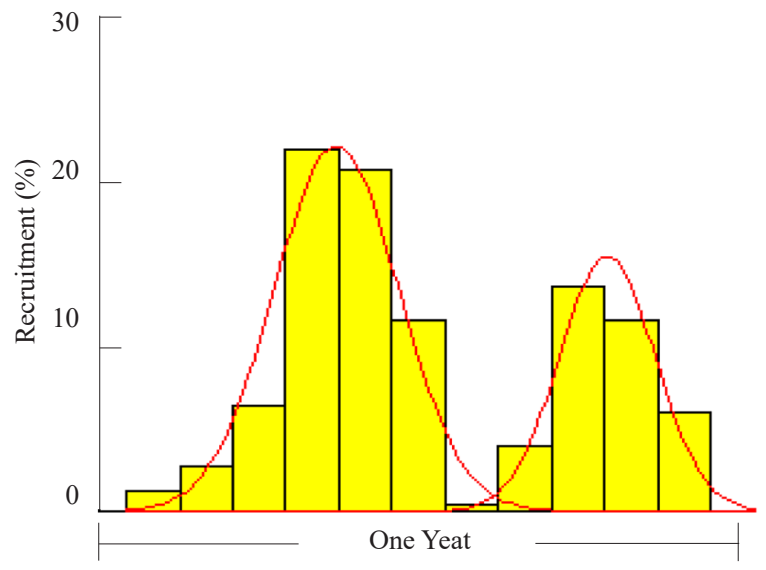

Fig. 5. Recruitment pattern of $S$. sindensis, indicating two peaks per year

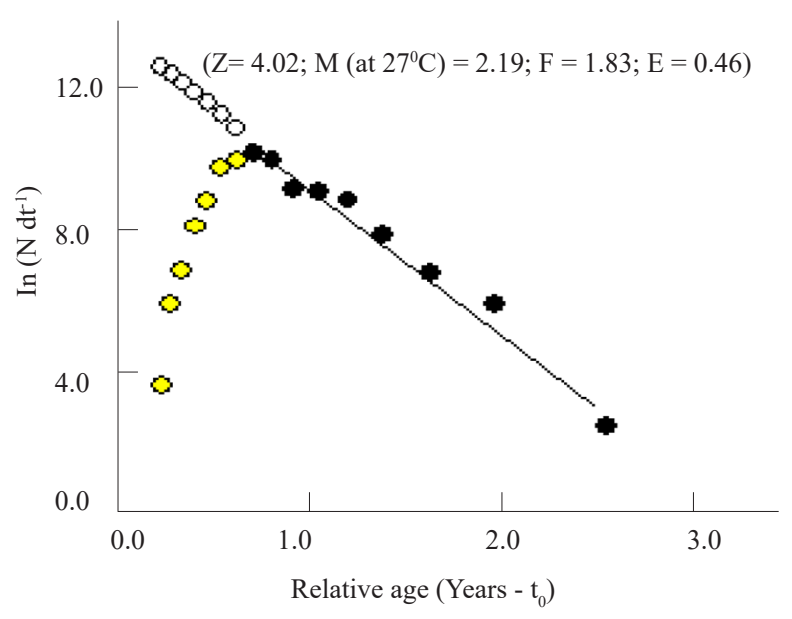

Fig. 6. Length-converted catch curve of $S$. sindensis 


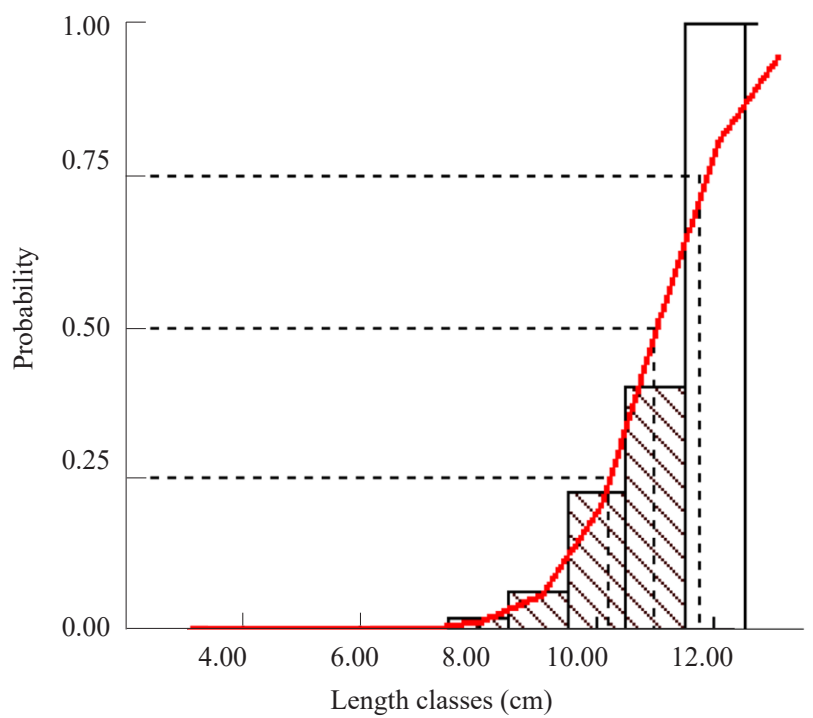

Fig. 7. Probability of capture of each length class of S. sindensis $\left(\mathrm{Lc}_{25}=10.2 \mathrm{~cm}, \mathrm{Lc}_{50}=10.9 \mathrm{~cm}, \mathrm{Lc}_{75}=11.8 \mathrm{~cm}\right)$

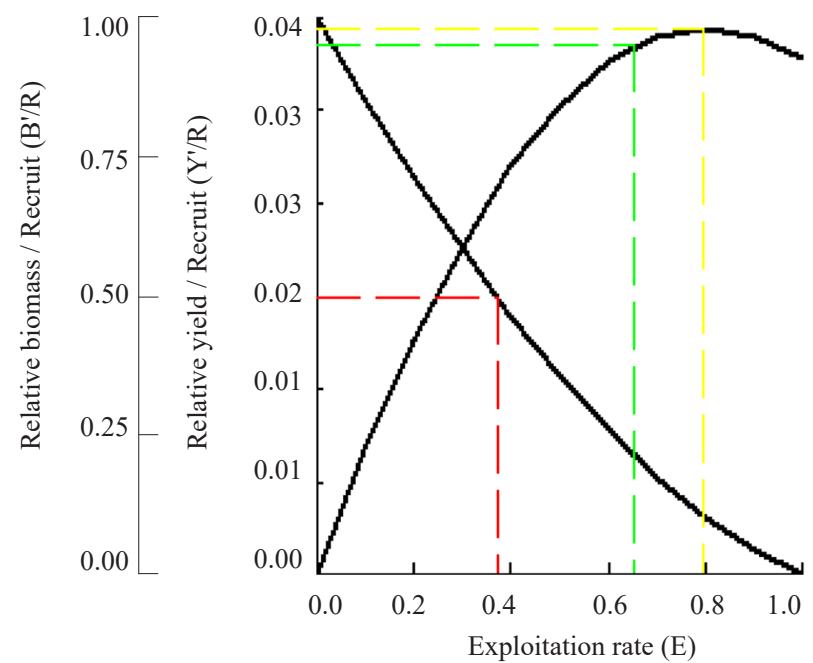

Fig. 8. Yield per recruit isopleths diagram with $\mathrm{M} / \mathrm{K}=1.82$ for S. sindensis

rates were estimated as: $\mathrm{E}_{\max }=0.79 ; \mathrm{E}_{0.1}=0.65 ; \mathrm{E}_{0.5}=0.37$. Optimum exploitation rate was 0.79 (Fig. 9).

\section{Discussion}

In this study, the total length of S. sindensis ranged from 5.0 to $19.9 \mathrm{~cm}$ with a mean of $13.0 \mathrm{~cm}$. The total length of S. sindensis in Pakistani waters ranged from 15.0 to $25.0 \mathrm{~cm}($ mean $\pm \mathrm{SD}, 17.8 \pm 1.50)$ (Elahi et al., 2015). The total length of Sind sardinella from Karachi area in Pakistan was reported to be between 11.0 and $20.9 \mathrm{~cm}$ (Safi and Hashmi, 2013) and in Qeshm Island (the Persian Gulf) was between 8.1 and $18.2 \mathrm{~cm}$ (Dehghani et al., 2015). Observed differences in total length of the fishes in these

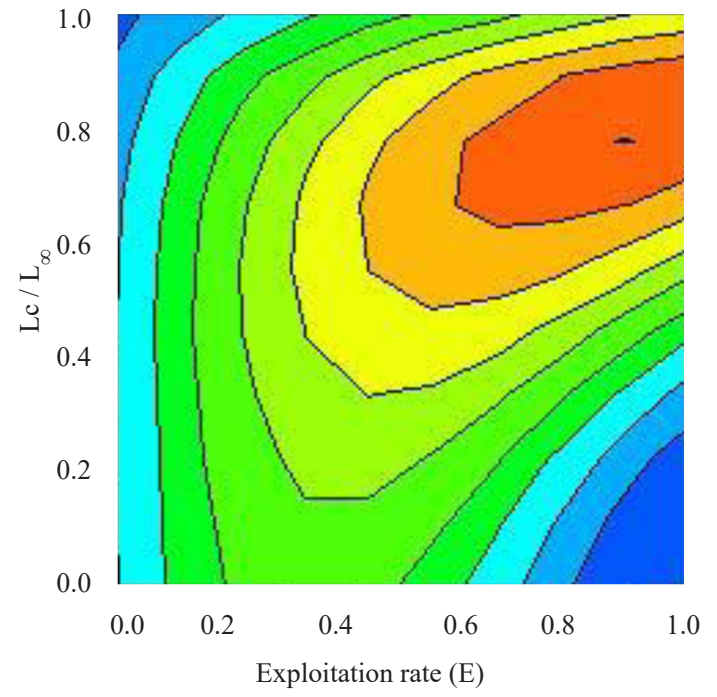

Fig. 9. Relative yield-per-recruit and relative biomass-per-recruit as computed using ogive selection $\left(\mathrm{E}_{\max }=0.79, \mathrm{E}_{0.1}=0.65\right.$, $\left.\mathrm{E}_{0.5}=0.37\right)$.

populations are probably related to differences in applied fishing gears, mesh size, skewness in sampling, ecological conditions, seasons, habitats and interspecific differences, as observed in other fish species (Alavi-Yeganeh et al., 2011; Daneshvar et al., 2013; Ghanbarifardi et al., 2014; Asadollah et al., 2017).

The $S$. sindensis stock appears to be in a healthy condition in the coastal waters of the Persian Gulf and Oman Sea, as a wide range of size classes were present in the catch. Normal distribution in length-frequency data confirms that the stock is not exposed to high fishing pressure (Gayanilo and Pauly, 1997).

Length and weight data are essential for estimating many aspects of fish population dynamics and the relationship between these two parameters is important for stock assessment (Gulland and Rosenberg, 1992). The value of $b$ in the length-weight relationship derived in the present study is similar to that estimated earlier for the same species from the area (FAO, 1981; Dehghani et al., 2015). The length-weight relationship may be influenced by age, maturity, sex, geographic location and associated environmental conditions, such as season (date and time of capture), diseases and parasites (Haimovici and Canziani, 2000).

The von Bertalanffy growth data available for the coastal waters of the Persian Gulf and Oman Sea (this study) and coastal waters of Bandar-Jask (Oman Sea) (Farkhondeh et al., 2010; Alaei et al., 2013) indicate that $S$. sindensis in these regions have similar growth rates and also attain a similar maximum size, while the data 
available for the Qeshm Island (Salarpouri et al., 2008) provide contrasting results (Table 1). However, it is not known to what degree these differences in growth patterns are influenced by regional differences in biological productivity, stock-dependent genetic differences in growth performance and the selectivity in fishing gear used in each study.

A comparison of growth performance index (Ø) between $S$. sardinella and other sardines from different sources is also shown in Table 1. Generally, the growth performance index is a species-specific parameter, i.e., its values are usually similar within related taxa and also have narrow normal distributions. The gross dissimilarity of $\varnothing$ for a number of stocks of the same species or related species is an indication of the unreliability in the accuracy of the estimated growth parameters (Moreau et al., 1986). It is notable that $\varnothing$ can only be used to compare the growth performance of fish with similar shapes (Gayanilo et al., 2005). Moreau et al. (1986) suggested that the coefficient of variation (CV) of $\varnothing$ for several stocks of the same species should not exceed 5\%, which may provide some indication of credibility of the obtained values for $\varnothing$ (Gayanilo and Pauly, 1997). The coefficient of variation of $4.82 \%$ together with other measurements of dispersion (range $=0.35$, variance $=0.01$, standard deviation $=0.13$ and mean $=2.68$ ) for $\varnothing$ values in Table 1 are low. There are some differences between the value of $\varnothing$ of Sind sardinella in this study and that of some other studies. Such differences could partially be derived from difference in the used techniques but they could also be related to slight environmental differences such as food availability, temperature and salinity. (Ragonese and Bianchini, 1998). The similarity in the relative growth performance of this tropical sardine and those from other regions suggests that phylogeny independent of local environmental conditions may influence growth. It also suggests that their position in the food web as lower-order secondary consumers places a constraint on overall growth performance in any environment (Milton et al., 1993).

Four cohorts and two recruitment peaks were determined annually which conform with the assertion of Pauly (1982) on the existence of two recruitment pulses per year for tropical fish species. Sardines and anchovies manifest some peculiarities in their population dynamics and there are some interesting phenomena in relation to their recruitment (Bakun, 2010; Petitgas et al., 2012). The length and age at recruitment of $S$. sindensis in the Persian Gulf were reported to be $2.5 \mathrm{~cm}$ and 0.15 year, respectively (Van Zailinge et al., 1993). Tropical species are known to have recruitment through out the year (Sparre and Venema, 1998). Recruitment of small pelagic fishes, especially clupeoids fluctuates widely in response to both fishing and environmental effects. Yet, their life history style is extremely flexible and enables populations to persist, even at very low levels (Beverton, 1990).

The values of total instantaneous mortality rate and the exploitation rate obtained in this study were in the range of those obtained for other Sardinella species of Tawi-Tawi, Philippines (Aripin and Showers, 2000) and of the west coast of India (Annigeri et al., 1992) (Table 2). Although, there are some similarities between the values of the natural mortality in this study and other previous studies on other Sardinella species, these similarities on the values of fishing mortality are very low (Table 2 ).

Gulland (1971) suggested that, as a rule of thumb, a fish stock is optimally exploited at a level of fishing mortality which generates $\mathrm{E}=0.50$, where $\mathrm{F}_{\text {opt }}=\mathrm{M}$. In the present study, the estimated value of the exploitation rate (E) confirms that the stocks of $S$. sardinella in the coastal waters of the Persian Gulf and Oman Sea are not exposed to high fishing pressure yet and they are in a healthy condition.

Table 1. Comparison of growth performance in selected species of Sardinella, $\mathrm{L}_{\infty}$ (asymptotic length), K (growth coefficient) and $\varnothing$ (growth performance index) $($ Mean $=2.68$, Range $=0.35, C V=4.82$, S.D. $=0.13$, Variance $=0.01)$.

\begin{tabular}{llllll}
\hline Species & $\varnothing$ & $\mathrm{L}_{\infty}$ & $\mathrm{K}$ & Area & Source \\
\hline S. albella & 2.51 & 16.8 & 1.11 & Dar es Salaam (Tanzania) & Makwaia and Nhwani (1992) \\
S. albella & 2.50 & 17.0 & 1.18 & Gulf of Manar (India) & Bennet et al. (1992) \\
S. gibbosa & 2.79 & 17.1 & 1.08 & Mandapam (India) & Banerji and Krishnan (1973) \\
S. gibbosa & 2.66 & 19.5 & 1.20 & Coastal waters (Indonesia) & Dwipongo et al. (1986) \\
S. longiceps & 2.65 & 22.0 & 1.21 & Oman Sea (Oman) & Al-Anbouri et al. (2012) \\
S. longiceps & 2.79 & 21.0 & 1.40 & South-west coast (India) & Biradar and Gjosæter (1989) \\
S. longiceps & 2.85 & 21.6 & 1.50 & Malabar coast (India) & Ganga and Pillai (2006) \\
S. sindensis & 2.55 & 17.8 & 1.11 & Qeshm Island & Salarpouri et al. (2008) \\
S. sindensis & 2.75 & 20 & 1.40 & Jask area (Oman Sea) & Farkhondeh et al. (2010) \\
S. sindensis & 2.65 & 19.5 & 1.18 & Bandar-Jask (Oman Sea) & Alaei et al. (2013) \\
S. sindensis & 2.72 & 21 & 1.20 & Persian Gulf and Oman Sea (Iran) & This study
\end{tabular}


Table 2. Comparison of mortality and exploitation rates of selected species of Sardinella

\begin{tabular}{|c|c|c|c|c|c|}
\hline \multirow{2}{*}{$\begin{array}{l}\text { Source } \\
\text { Species }\end{array}$} & \multicolumn{3}{|c|}{ Aripin and Showers (2000) } & \multirow{2}{*}{$\begin{array}{l}\text { Annigeri et al. (1992) } \\
\text { S. longiceps }\end{array}$} & \multirow{2}{*}{$\begin{array}{l}\text { This study } \\
\text { S. sindensis }\end{array}$} \\
\hline & S. albella & S. longiceps & S. fimbriata & & \\
\hline Total mortality (Z) & 6.1 & 3.65 & 4.23 & 2.32 & 4.02 \\
\hline Natural mortality (M) & 2.62 & 1.97 & 2.63 & 1.3 & 2.19 \\
\hline Fishing mortality $(\mathrm{F})$ & 3.48 & 1.68 & 1.6 & 0.93 & 1.83 \\
\hline Exploitation rate (E) & 0.57 & 0.54 & 0.62 & 0.41 & 0.46 \\
\hline
\end{tabular}

With a maximum age of 2.5 years, Sind sardinella is a relatively short-lived species and this is confirmed by the high natural mortality recorded in this study. In addition, this result confirms the superimposed growth curve (Fig. 4) from restructured length-frequency. The maximum age of $S$. sindensis in the Qeshm Island was estimated at 3.5 years using otoliths (Dehghani et al., 2015). Intuitively, we would consider longevity as a parameter which is more closely related to mortality than $\mathrm{K}, \mathrm{L}_{\infty}$ or ambient temperature. Since, longevity is usually as difficult as natural mortality to observe, the relationship between mortalities and lifespan is not suitable for estimation of $\mathrm{M}$, but it could help obtain this relationship easier (Sparre and Venema, 1998). Short-lived tropical species grow more rapidly than other tropical resident species, suggesting that they may have better growth performance (Milton et al., 1993).

Beverton and Holt (1957) found that the ratio of $\mathrm{M} / \mathrm{K}$ in fishes is mostly between 1.5 and 2.5 . In this study, the ratio of $\mathrm{M} / \mathrm{K}$ for Sind sardinella was estimated at 1.82 . Based on the critical size, the ratio of $\mathrm{L}_{c 50} / \mathrm{L}_{\infty}$ (which is a representative of mesh size) and the exploitation rate (E) (which is a representative of effort), Pauly and Soriano (1986) have shown that the relative yield isopleths could be classified to four categories (quadrants) with distinct properties. Accordingly and considering the calculated values of the $\mathrm{Lc}_{50} / \mathrm{L}_{\infty}(0.52)$ and the exploitation rate $(0.46)$ in this study, the relative yield isopleths of $S$. sindensis is within quadrant A of Pauly and Soriano (1986). This means that small specimens are caught at lower level of effort. The analyses of the mortality rates, exploitation rates, yield-per-recruit and biomass-per-recruit carried out here indicate that the purse seine fishery of $S$. sardinella in the coastal waters of the Persian Gulf and Oman Sea does not exert considerable fishing pressure on the stock. sardine fishery is in a growth phase, confirming the reliable potential of sardine stocks in the region. Regular monitoring of the effort level and the exploitation rate (E) is required for sardine stocks in the region, but there is no need for interventions at this stage.

\section{Acknowledgements}

The authors are grateful to Dr. M. S. Mortazawi, Head, Persian Gulf and Oman Sea Ecological Research
Institute, for cooperation and facilities, and to P. Mohebbi, Head, Hormozgan Fisheries Organization, for facilities. Acnowledgements are also due to field assistants Reza Darvish, Qasem Farkhondeh, Ahmad Mahmoodi and Hossein Rameshi.

\section{References}

Alaei, A., Paighambari, S. Y., Salarpouri, A. and Mazaheri, Z. 2013. Study of some population dynamic parameters of Sind sardinella (Sardinella sindensis) in coastal waters of Bandar-Jask . J. Aqua. Ecol., 3(3): 25-34 (in Persian).

Al-Anbouri, I., Ambak, M. and Jayabalan, N. 2012. Studies on the age, growth and mortality rates of Indian oilsardine, Sardinella longiceps Valenciennes, 1847 off Oman Sea, Muscat, Sultanate of Oman. J. Biol. Agric. Healthcare, 1(4): 19-26.

Al-Barwani, M., Prabhakar, A., Dorr, M. and Al-Mandhery, M. 1989. Studies on the biology of Sardinella longiceps (Valenciennes) in the Sultanate of Oman, 1985-1986. Kuwait Bull. Mar. Sci., 10: 201-209.

Alizade, E. and Oliaei, M. 2015. Report of fisheries statistics of Hormozgan Province, Iran. Hormozgan Province Fisheries Department, Iran, 88 pp (in Persian).

Alavi-Yeganeh, M. S., Seifabadi, S. J., Keivany, Y., Kazemi, B. and Wallis, G. P. 2011. Comparison of length-weight relationships in different populations and sexes of Iranian thoothcarps. J. Appl. Ichthyol., 27: 1401-1403.

Annigeri, G. G., Kurup, K. N., Kumaran, M., Mohan, M., Luther, G., Nair, P. N. R., Rohit, P., Kulkarni, G. M., Gnanamuttu, J. C. and Roa, K. V. N. 1992. Stock assessment of oil sardine, Sardinella longiceps, off west coast of India. Indian J. Fish., 39 (3 and 4): 125-135.

Aripin, I. E. and Showers, P. A. T. 2000. Population parameters of small pelagic fishes caught off Tawi-Tawi, Philippines. Naga, 23 (4): 21-27.

Asadollah, S., Soofiani, N. M., Keivany, Y. and Hatami, R. 2017. Age and growth of the mesopotamian barb, Capoeta damascina, in Central Iran. Iran. J. Fish. Sci., 16(2): 511-521.

Bakun, A. 2010. Linking climate to population variability in marine ecosystems characterized by non-simple dynamics: conceptual templates and schematic constructs. J. Mar. Sys., 79(3): 361-373. DOI: 10.1016/j.jmarsys.2008.12.008.

Banerji, S. K. and Krishnan, T. S. 1973. Acceleration of assessment of fish populations and comparative studies of similar taxonomic groups. In: Proceedings of the 
Symposium on living resources of the seas around India, CMFRI Special Publication, Central Marine Fisheries Research Institute, Kochi, India, p.158-175.

Barange, M., Coetzee, J., Takasuka, A., Hill, K., Gutierrez, M., Oozeki, Y. and Agostini, V. 2009. Habitat expansion and contraction in anchovy and sardine populations. Prog. Oceanogr., 83(1): 251-260.

Bennet, P. S., Nair, P. N. R., Luther, G., Annigeri, G. G., Rangan, S. S. and Kurup, K. N. 1992. Resource characteristics and stock assessment of lesser sardines in the Indian waters. Indian J. Fish., 39 (3 and 4): 136-151.

Beverton, R. J. H. 1990. Small marine fish and the threat of fishing, are they endangered? J. Fish Biol., 37: 5-16. https://doi.org/10.1111/j.1095-8649.1990.tb05015.x.

Beverton, R. J. H. and Holt, S. J. 1957. On the dynamics of exploited fish populations. Fish. Investig., 2(9): 533.

Biradar, R. S. and Gjosæter, J. 1989. Population dynamics of Indian oil sardine, Sardinella longiceps, off the south-west coast of India. J. Appl. Ichthyol., 5(4): 185-193.

Blaxter, J. H. S. and Hunter, J. R. 1982. The biology of the clupeoid fishes. Adv. Mar. Biol., 20: 1-223. https://doi. org/10.1016/S0065-2881(08)60140-6.

Cole, J. and Mc Glade, J. 1998. Clupeoid population variability. The environment and satellite imagery in coastal upwelling. Rev. Fish Biol. Fish., 8: 445-471.

Cushing, D. H. 1971. The dependence of recruitment on parent stock in different groups of fishes. J. du Con. Con. Int. pour L'Exploration de la Mer., 33: 340-362.

Daneshvar, E., Keivany, Y. and Paknehad, E. 2013. Comparative biometry of the Iranian cichlid, Iranocichla hormuzensis, in different seasons and sexes. Res. Zool., 3: 56-61.

Darvishi, M. 2008. Biology and assessment of Spanish king mackerel (Scomberomorus commerson) in Hormuzgan Province. M. Sc. Thesis, Islamic Azad University, Bandar Abbas, Iran, 183 pp. (in Persian).

Darvishi, M., Behzadi S. and Salarpouri A. 2003. Spawning, fecundity and feeding of longtail tuna (Thunnus tonggol) in the Persian Gulf and Oman Sea, Hormuzgan Province J. Res. Develop., 59: 70-75. (in Persian).

Dehghani, M., Kamrani, E., Salarpouri, A. and Kamali, E. 2015. Age and growth of Sind sardine (Sardinella sindensis) using otolith from Qeshm Island (Persian Gulf). Iran. J. Fish. Sci., 14(1): 236-250.

Devaraj, M., Kurup, M., Pillai, N., Balan, K., Vivekanadan, E. and Sathiadas, R.1997. Status, prospects and management of small pelagic fisheries in India. In: Devaraj, M. and Matosubroto, P. (Eds.), Small pelagic resources and their fisheries in the Asia-Pacific region, First Session, 13-16 May, 1997, Bangkok, Thailand. RAP publication 1997/31, p. $91-138$
Dwipongo, A., Hariati, T., Banon, S., Palomares, M. L. and Pauly, D. 1986. Growth, mortality, and recruitment of commercially important fishes and penaeid shrimps in Indonesian waters. ICLARM Tech. Rep., 17: $91 \mathrm{pp}$.

Ebrahimi, M., Mortazawi, M., Ejlali, K., Aghajari, N., Jokar, K., Akbarzadeh, G., Seraji, F. and Aghajari, S. 2005. Hydrology and hydrobiology studies on the Persian Gulf in Hormozgan, south of Iran, Iranian Fisheries Research Organization, 130 pp. (in Persian).

Ebrahimi, M., Mohebbi, L., Seraji, F., Eslami, F., Salimizadeh, M. and Aghajari, S. 2006. Hydrology and hydrological monitoring in the north-eastern part of the Persian Gulf and Strait of Hurmoz, Hormozgan Province water, Iranian Fisheries Research Organization, 109 pp, (in Persian).

Ebrahimi, M., Khodadadi, A., Jokar, K. and Azini, M. 2012. Study on physicochemical properties of the Iranian waters in the Oman Sea, Iranian Fisheries Research Organization, 100 pp (in Persian).

Elahi, N., Farzana Yousuf, S. T. and Raza, A. 2015. Lengthweight relationship (lwr), condition factor and seasonal distribution of Sardinella sindensis (Day, 1878) through size frequency variation from the Balochistan Coast, Pakistan. Int. J. Fauna Biol. Studies, 2(3): 96-99.

FAO 1981. Pelagic resources of the Persian Gulf and the Gulf of Oman regional fishery survey and development project, Food and Agriculture Organisation, Rome, Italy, 144 pp.

FAO 2011. Report of the FAO Workshop on the status of shared fisheries resources in the northern Arabian Sea - Iran, Oman and Pakistan. 13-15 December 2010, Muscat, Oman. FAO Fisheries and Aquaculture Report. No. 971, Food and Agriculture Organisation, Rome, Italy, $58 \mathrm{pp}$.

Farkhondeh, Gh., Valinassab, T. and Kamrani, E. 2010. Growth parameters and mortality rates of Sardinella sindensis in the coastal waters of Jask area. Sci. J. Aquat. Org. Fish., 1(3): $70-80$ (in Persian).

Ganga, U. and Pillai, N. 2006. Comparison of the growth of oilsardine Sardinella longiceps Val., off Vishakhapatnam and Malabar coasts. Indian J. Fish., 53(4): 449-453.

Ganias, K. 2014. Biology and ecology of sardines and anchovies. CRC Press. Boca Raton, Florida, USA, 367 pp. DOI:https:// doi.org/10.1201/b16682.

Gayanilo, F. C. and Pauly, D. 1997. FAO-ICLARM Stock Assessment Tools (FiSAT). Reference Manual. FAO Computerised Information Series (Fisheries) No. 8. Food and Agriculture Organisation, Rome, Italy, $262 \mathrm{pp}$.

Gayanilo, F. C., Sparre, P. and Pauly, D. 2005. FAO-ICLARM Stock Assessment Tools II (FiSAT II). Revised version. User's guide. FAO Computerized Information Series (Fisheries) No. 8. Revised version. Food and Agriculture Organisation, Rome, Italy, 168 pp.

Ghanbarifardi, M., Ghasemian, S., Aliabadian, M. and Pehpuri, A. 2014. Length-weight relationships for three species of mudskippers (Gobiiformes: Gobionellidae) in the 
coastal areas of the Persian Gulfand GulfofOman, Iran. Iran. J. Ichthyol., 1: 29-31.

Gulland, J. A. 1971. The fish resources of the ocean. Fishing News (Books) Ltd., Surrey. England, 255 pp.

Gulland, J. A. and Rosenberg, A. A. 1992. A review of length-based approaches to assessing fish stocks. FAO Fisheries Technical Paper. No. 323, Food and Agriculture Organisation, Rome, Italy, $100 \mathrm{pp}$.

Haimovici, M. and Canziani, G. V. 2000. Length-weight relationship of marine fishes from Southern Brazil. Naga, ICLARM Q., 23(1): 19-23.

Iran, M. 1998. Report on small pelagic fisheries statistics in south Iranian coastal waters. Iranian Fisheries Research Institute, Bandar Abbass Center, 44 pp. (in Persian).

Kesteven, G. L., Nakken, O. and Stromme, T. 1981. The smallpelagic and demersal fish resources of the north-west Arabic Sea surveys 1975-1976. Reports of Surveys with the $R / V$ Dr. FRIDTJOF NANSEN. Institute of Marine Research, Bergen, 143 pp.

Khatoon, Z. and Hussain, S. 1998. Description of eggs and developmental stages of Sardinella sp. with notes on their abundance and distribution in the backwaters of Karachi Harbour. Pak. J. Zool., 30(2): 143-149.

King, M. 2013. Fisheries biology assessment and management fishing. $2^{\text {nd }}$ edn.. Blackwell Publishing Ltd., Oxford, UK, $382 \mathrm{pp}$.

Lazarus, S. 1980. Redescription of Sardinella sindensis (Day) (Pisces: Clupeidae) with notes to distinguish the species from S. gibbosa (Bleeker). J. Mar. Biol. Ass. India, 22 (1 and 2): 57-62.

Makwaia, E. and Nhwani, L. 1992. Population parameters of Sardinella species in the coastal waters of Dar es Salaam, Tanzania. Naga, ICLARM Q., 15(1): 25-28.

Milton, D., Blaber, S. and Rawlinson, N. 1993. Age and growth of three species of clupeids from Kiribati, tropical central south Pacific. J. Fish Biol., 43(1): 89-108. DOI: 10.1111/ j.1095-8649.1993.tb00413.x.

Moreau, J., Bambino, C. and Pauly, D. 1986. Acomparison of four indices of overall growth performance based on 100 tilapia populations (Fam. Cichlidae). In: Maclean, J. L., Dizon, L. B. and Hosillos, L. V. (Eds.), The First Asian Fisheries Forum. Asian Fisheries Society, Manila, Philippines, p. 201-206.

Owfi, F. 1991. Report on sardine fishes from the Persian Gulf and Oman Sea. Iranian Fisheries Research Institute, Bushehr Center, Iran, 7 pp. (in Persian).

Owfi, F. 1994. A survey on biology and stocks of sardine fishes from the Persian Gulf. Iranian Fisheries Research Institute, Bushehr Center, Iran, 47 pp. (in Persian).

Pauly, D. 1980. On the interrelationships between natural mortality, growth parameters, and mean environmental temperature in 175 fish stocks. $J$. du Con., 39(2): 175-192. https://doi.org/10.1093/icesjms/39.2.175.
Pauly, D. 1982. Studying single-species dynamics in tropical multi-species context. In: Pauly, D. and Murphy, G. I. (Eds.), ICLARM Conference proceedings on theory and management of tropical fisheries, 9: 33-40.

Pauly, D. 1983. Some simple methods for the assessment of tropical fish stocks. FAO Fisheries Technical Paper. No. 234, Food and Agriculture Organisation, Rome, Italy, 52 pp.

Pauly, D. 1987. A review of the ELEFAN systems for analyzing of length-frequency data in fish and aquatic invertebrates. In: Pauly, D. and. Morgan, G. R (Eds.), Length-based methods in fisheries research. ICLARM Conference Proceedings, 13: 7-34.

Pauly, D. and Munro, J. 1984. Once more on the comparison of growth in fish and invertebrates. Fishbyte, 2(1): 1-21.

Pauly, D. and Soriano, M. L. 1986. Some practical extension to the Beverton and Holt's relative yield-per-recruit model. In: Maclean, J. L., Dizon, L. B. and Hosillo, L.V. (Eds.), Proceedings of the First Asian Fisheries Forum. Asian Fisheries Society, Manila, Philippines, p. 491-496.

Petitgas, P., Alheit, J., Peck, M. A., Raab, K., Irigoien, X., Huret, M. and Dickey-Collas, M. 2012. Anchovy population expansion in the North Sea. Mar. Ecol. Prog. Ser., 444: 1-13.

Qorbanzadeh, R. and Nazari, S. 2012. Statistical Yearbook of the Iranian Fisheries Organization. Department of Planning and Development Management, Iranian Fisheries Organization, Tehran, Iran, 60 pp. (in Persian).

Ragonese, S. and Bianchini, M. L. 1998. Growth, mortality, and yield-per-recruit of the poor cod, Trisopterus minutus capelanus, from the Strait of Sicily. Naga, ICLARM Q., 21(1): 61-70.

Rahimi, P., Rezvani Gilkolaei, S., Ghavam Mostafavi, P., Jamili, S. and Rahnema, M. 2016. Population genetics of Sind sardine, Sardinella sindensis, in the Persian Gulf and Oman Sea by analysis of mitochondrial control region. In: Proceedings of the $2^{\text {nd }}$ International and $14^{\text {th }}$ Iranian Genetics Congress, 21-23 May 2016, Shahid Beheshti University. Tehran, Iran.

Randall, J. E. 1995. The complete divers and fisherman's guide to coastal fishes of Oman. University of Hawaii Press, Honolulu, Hawaii, USA, 439 pp.

Safa, S. 2011. Shape analysis of otolith in Sind sardinella (Sardinella sindensis) stocks in the Persian Gulf and Oman Sea (Hormuzgan Province). M. Sc. Thesis, Hormozgan University, Bandar Abbas, Iran.

Safi, A. and Hashmi U. A. 2013. Studies on gonadosomatic index (GSI) and sex ratio of Sind sardine fish, Sardinella sindensis (Day, 1878) (Family: Clupeidae) of Karachi coast, Pakistan. Int. J. Biol. Res., 1(2): 34-40.

Salarpouri, A., Behzadi, S., Darvishi, M. and Momeni, M. 2008. Population dynamics of Sind sardinella, Sardinella sindensis, in coastal waters of Qeshm Island. Iran. Sci. Fish. J., 17(3): 77-86 (in Persian). 
Schwartzlose, R. A., Alheit, J., Bakun, A., Baumgartner, T. R., Cloete, R. J., Crawford, M. and Zuzunaga, J. Z. 1999. Worldwide large-scale fluctuations of sardine and anchovy populations. South Africa. J. Mar. Sci., 21(1): 289-347.

Shawghi, H. 1992. Biology of tuna fishes. Iranian Offshore Fisheries Research Centre, Iranian Fisheries Science Research Institute, Tehran, Iran, 80 pp. (in Persian).

Sivakumaran, K., Manickasundaram, M. and Ramaiyan, V. 1987. Problems of identification among species of Sardinella. Proceedings of the National Symposium on Research and development in marine fisheries, Sessions I and II, CMFRI Bulletin 44(1). Central Marine Fisheries Research Institute, Kochi, p. 223-226.
Sparre, P. and Venema. S. C., 1998. Tropical fish stock assessment, Part 1, JManual. Food and Agriculture Organisation, Rome, Italy, $337 \mathrm{pp}$.

Van Zailinge, N. P., Owfi, F., Ghasemi, S., Khorshidian, K. and Niamaimandi, N. 1993. Resources of small pelagics in Iranian waters - a review. FAO/UNDP Fisheries Development Project Ira/83/013, Food and Agriculture Organisation, Rome, Italy, $370 \mathrm{pp}$.

Whitehead, P. J. P. 1985. FAO species catalogue, vol. 7, Clupeoid fishes of the world. An annotated and illustrated catalogue of the herrings, sardines, pilchards, sprats, anchovies and wolfherrings. Part I - Chirocentridae, Clupeidae, and Pristigasteridae. FAO Fisheries Synopsis. 125. vol. 7 Pt1, Food and Agriculture Organisation, Rome, Italy, 303 pp. 